\title{
PART 5. ECUMENICAL ACTIVITY OF METROPOLITAN ANDREY SHEPTYTSKY
}

In the multifaceted activitiy of the eminent ecclesiastical figure Metropolitan Andrey Sheptytsky, the central issue was the problem of the unity of the Churches and the ecumenical action, associated with it, which manifested itself throughout his conscious life. According to Metropolitan, at the pan-Slavic and then at the Ukrainian level, the essence of the unification problem is the establishment of relations of cooperation and, later, the unity between the Catholic and Orthodox churches. In modern science, the term "ecumenism" (from the Greek oikumene - the universe, the inhabited world) - the movement for the unification of religious confessions - includes at least three directions: 1) the movement for the unification of Christian confessions; 2) integration processes of nonChristian religions; 3) coordination of the actions of Christian ecumenical organizations with non-Christian ones ${ }^{238}$. The term "ecumenical movement" is also used, it means the unification movement of Christian churches, initiated at the 1910 World Missionary Conference in Edinburgh (Scotland). P.L. Jarotsky rightly points out that " Ukrainian Greek Catholic Church (UGCC) takes an active part in the ecumenical meetings from the side Ukraine. However, Ukrainian Orthodoxy, which is divided into several churches, remains outside the global ecumenical movement. It has a different general goal: to reach agreement, reconciliation and unification in Ukraine by establishing a Ukrainian ecumenical movement, supported by other Ukrainian Christian churches... The development of an ecumenical movement is a complex, contradictory process..."239.

Most researchers of A. Sheptytsky's life path and works agree that ecumenical ideas captured the future Metropolitan in a young age $\mathrm{a}^{240}$. This was caused by the general spiritual atmosphere of the late nineteenth

238 Філософія політики: Короткий енциклопедичний словник / Автор-упорядник Андрущенко В. П. та ін. К.: Знання України, 2002. С. 213.

${ }^{239}$ Політологічний енциклопедичний словник / Упорядник В. П. Горбатенко; За ред. Ю. С. Шемшученка, В. Д. Бабкіна, В. П. Горбатенка. 2-ге видання, доповнене і перероблене. К.: Генеза, 2004. С. 181-182.

${ }^{240}$ See.: Жуковський А. Митрополит Андрей Шептицький і православ'я. Науковий збірник УВУ. Мюнхен, 1992. С. 37-38.; Баран О. Митрополит Андрей Шептицький і його екуменічні ідеї. Украӥнський Історик. 1-4 (120-123). Т. 31. Нью-Йорк - Торонто - Київ Львів - Мюнхен, 1994. С. 183-184. 
century, when, as a result of the technological revolution, humanity had largely put international unity at the forefront and it seemed to be the right time to pursue the intention of creating or restorating the Universal Christian Church. It was no accident that at this same time such people lived and worked: V. Solovyov in Russia, Bishop J.-J. Strossmayer - in Croatia, A. Sheptytsky - in Galicia, and on the Pontifical Throne - Leo XIII with Secretary of the Secretariat of State, Cardinal M. Rampolla. Each of them, in their own way, however, all thought of one thing: how to keep the covenant of Jesus Christ about one Shepherd and one spiritual flock. It is not accidental that the named persons sought contacts with each other and were closely acquainted and sympathetic to each other.

Family traditions also played a role in the choice of A. Sheptytsky's life path. The Sheptytsky family gave Ukraine several prominent ecclesiastical figures of Catholic rites. Thus, in particular, Hieronym-Anton (1700-1799) was a bishop of the Roman Catholic rite of Polotsk, while Athanasius-Anton (1677-1746) was a bishop of Lviv, Galicia, Kamenets and also the honorary Archbishop-Metropolitan of Kyiv and of all Rus of the Greek Catholic rite; Leo (1714-1779) occupied the same positions as Athanasius-Anton, and Athanasius-Andrey (1734-1779) was a Bishop of the Catholic Rite of Perechyn $^{241}$. Inspite the fact that in the middle of the XIX century the Sheptytsky family experienced a fate, typical for the Ukrainian nobility - the final transition to Roman Catholic rite and, as a consequence, polonization these traditions continued to live on. No wonder that in 1911, taking from Lviv citizens a portrait of a son, made in honor of the 10th anniversary of his Metropolitan's activity, A. Sheptytsky's father, Ivan, said: "I assure you, gentlemen, that I am Ukrainian. In fact, I gave you the best I had and the most expensive" ${ }^{242}$. Something similar to this we can read in the memories of Sophia Sheptytska, Roman's mother: "Roman said to me more than once: "I know in detail what awaits me - the Poles will consider me Ukrainian, and the Ukrainians will treat me as a Pole, and in vain!"243. In the same work S. Sheptytska also noted that her son "suffered from a tribal strife of his people, and he depended not so much on bringing them together, but rather on obtaining for the Church of Christ the peoples, who were not true believers or who were unbelievers, even the Indians and Japanese"244. Therefore, at the age of 22, the future Metropolitan did not limit his ecumenical work solely to the conversion to Rome of Ukrainians who inhabited other territories and entered different states.

241 Тожецький Р. Митрополит Андрей Шептицький. Ковчег: Збірник статей 3 церковної історії. Львів, 1993. С. 101-112.

${ }^{242}$ Владика Андрей. Альманах «Гомону Украйни» на рік 1994. Торонто, 1991. С. 47.

${ }^{243}$ Молодість і покликання о. Романа Шептицького. Львів: Свічадо, 2015. С. 119.

${ }^{244}$ Молодість і покликання о. Романа Шептицького. Львів: Свічадо, 2015. С. 119. 
Significant influence on the formation of the views of young A. Sheptytsky and his decision to enter the bosom of the Greek Catholic Church had a trip to Kiev, made in 1887 . Here he becomes acquainted with the history, art, culture of Ukraine. In Kyiv, Sheptytsky found himself in the midst of a patriotic Ukrainian intelligentsia. He was greatly impressed by the historian Volodymyr Antonovych, a Pole by descent, who broke with the Polish and joined the Ukrainians, as well as the young Mykhailo Hrushevsky. In the same year, A. Sheptytsky visits Moscow, where he meets the eminent philosopher and poet Vladimir Solovyov, who defended the idea of unity of the Christian churches as one of the main foundations of the formation of God's humanity"245. That meeting marked the beginning of something more than just friendship. It was a rare meeting of minds during which V. Solovyov, without realizing it himself, left his legacy of unification to Sheptytsky - perhaps the only person who consistently but also critically tried to make his theory a reality ${ }^{246}$. It is necessary to agree with the great influence that V. Solovyov made on A. Sheptytsky. L. Husar noted: “...The similarity of the ideas of these two men is striking, so we can just say that A. Sheptytsky learned a lot from V. Solovyov. He did not take V. Solovyov literally, did not follow in everything, but the general vision of the unity of the Church and the unification of the Churches was clearly borrowed from V. Solovyov"247. Noteworthy is L. Husar's view that Metropolitan Sheptytsky "was not an ordinary blind imitator - he was so independent in his views that he could give a critical assessment. He could, no matter what, continue the fight where Solovyov clasped his hands and plunged into the apocalypse" 248 .

However, not only external influences led to the emergence of A. Sheptytsky's ecumenical worldview. Back in 1884, while studying at the Law Faculty of the University of Krakow and at the same time at a one-year military school, a studying that was was interrupted by a serious illness, Sheptytsky became interested in the austerity of the Eastern Church and became fascinated with Greek patristics. Therefore, he supplemented his law education with philosophical and theological studies, receiving the title of Doctor of Laws, Theology and Philosophy.

Thus, long before becoming a monk, A. Sheptytsky had a clear purpose for his future activities, preparing for a difficult but noble mission: the

${ }^{245}$ More on V. Solovyov's ecumenical views see: Соловьев В. С. Россия и вселенская церковь. Минск: Харвест, 1999. 1600 с.

246 Гузар Л. Андрей Шептицький Митрополит Галицький (1901-1944) провісник екуменізму. Жовква: Місіонер, 2015. С. 52.

${ }^{247}$ Ibid. C. 59.

${ }^{248}$ Гузар Л. Андрей Шептицький Митрополит Галицький (1901-1944) провісник екуменізму. Жовква: Місіонер, 2015. С. 68. 
struggle for the rapprochement and unification of the Western and Eastern Churches. On March 24, 1888, A. Sheptytskyy received a special audience by Pope Leo XIII, whom he confessed of his desire to become a monk of the rank of St. Basil the Great and of his plans for the union of the Churches. That same time the Pope blessed the young enthusiast for the realization of these unusual designs. It should be noted that this was their third meeting: the first was held on May 9, 1886, the second was held on February 8, 1888.

Thus, the case of the union of the Orthodox believers - Ukrainians, Russians and Belarusians - with the Apostolic Capital was the main motivation for Roman Sheptitsky's conversion from Roman Catholicism to the Union. He did not stop working to achieve this goal for the rest of his life.

However, while remaining invariably the main nerve of his multifaceted activity, the Metropolitan's views on ways to solve the problem of unity of the churches were not constant, they had been always concretizing. This gave a basis to the misrepresentation and falsification of his ideas in tsaristRussian, Polish and Soviet official historiography. These accusations have the only source, which is embodied in the slogan: "Whoever is not with us, he is against us" - an attempt to impose a single, eternal and unchanging truth (of course, their own), which is often implicated in hatred of all "dissenters". Therefore, the convictions of Metropolitan, who was "a person belonging to the whole nation and standing above parties" ${ }^{249}$, provoked a fierce opposition from the enemies of the Ukrainian people. However, it would have been strange otherwise: if A. Sheptytsky did not reconcile his activity with the change of socio-political and economic realities, which Ukraine repeatedly suffered during his stay in the Metropolitan's order.

In justifying the possibilities of joining the Churches, A. Sheptytsky turns first to the Holy Scriptures, to the New Testament commands of Christ. Metropolitan A. Sheptytsky believed that church ceparation was a denial of the Spirit of Christ and the commandment of Christ, and an evil example for non-Christians. However, the presence of this ceparation is not a basis for pessimism, because it can be overpassed. According to A. Sheptytsky, in the Christian doctrine there is a union everywhere: in the Holy Trinity, in the God-human, and between God and people. Although a human was individually accepted into the body of God, now, in the mystical body, he is becoming part of the mystical community. It must contain harmony and love, which, according to A. Sheptytsky, are the reflection of the "unity" of the Holy Trinity. He describes his vision of church unity in such an example where Church is the bridge between God and people. People who want to unite with God must cross this bridge together because only this path leads

${ }^{249}$ Український прапор. 1921. 21 лютого. 
to the Lord. There is no room for controversy or strife on that bridge, no room for obstacles - there is only one direction and one purpose.

Finally, A. Sheptytsky emphasizes, the Doctrine of Divine Revelation needs the unity. Although, "in the depths of the revealed truth there is already everything that the Church will ever proclaim and that the Church Fathers, bishops and priests will ever preach" 250 , the Holy Scripture "is not as clear as Luther and most of the reformed theologians claimed" ${ }^{251}$. The reason for this is the symbolic and figurative presentation of the Holy Scripture. That is why the famous Ukrainian philosopher H. Skovoroda called the Bible a symbolic world. Such a form is polysemantic, that is, it allows for multivariate content, including inadequate ones. Therefore, $\mathrm{Kyr}$ Andrey likens the construction of the Doctrine of Divine Revelation to the construction of a great temple, which is the work of God Almighty, but also requires the cooperation of all Christians. "Even though people of all nations and all generations of the world work in that structure, it is one-of-a-kind, such one case, which clearly shows that it is the fulfillment of God's plan, Christ's plan. One style, one greatness, one power, one beauty is in that temple, one spirit is in that science. Those millions of people working on that science are something one, something united by the spirit of Christ, and they are no more than a harmonized choir composed of thousands of voices. They all are unmistakable together, because St. Spirit leads them, but everyone in particular can be wrong, and very ofthen they are wrong. Even the greatest ecclesiastical teachers, in some details, had different opinions from the general community, and because of that they were mistaken... But every mistake was always fixed by a guess, by the common science" ${ }^{252}$.

Concretizing the general ecumenical ideas of the universal unity of the Christian churches, Metropolitan Andrey Sheptytsky in his numerous works gives a thorough analysis of the question of what is common in Catholicism and Orthodoxy, and what hinders their union ${ }^{253}$. It is naturally that in the Ukrainian context these two branches of Christianity are the focus of his attention.

A. Sheptytsky refers to issues in which there are no differences between them. He mentiones the common Symbol of the confession of faith, books of the Old and New Testaments, acknowledgment of all decisions of the Ecumenical Councils from the First Council of Nicaea (325) to the Second

${ }^{250}$ Ibid.C. 31.

${ }^{251}$ Ibid. C. 74.

252 Шептицький Андрей. Листи-послання (1939-1944). Львів, 1991. С. 31-32.

${ }^{253}$ It is appropriate to note that some researchers consider the definitions of "union" and "ecumenism" different in content. In the first case, in their opinion, it is a question of the unity of churches, in the second - only their mutual knowledge and rapprochement. (See: Жуковський А. Названа праця. С. 46-47). We use these definitions as similar. 
Council of Nicaea (787). So, he states, until the XI century there was a single Ecumenical Church, the doctrine of which was accepted by St. Volodymyr during the christening of Rus.

The main definitions of the Catholic Church, given by the following Ecumenical Councils, which are not accepted by the Orthodox Church, according to A. Sheptytsky, are next: the Immaculate Conception of Virgin Mary, the origin of St. Spirit from the Father and the Son, and recognition of the primacy of the jurisdiction of the Roman Archiereus over the whole Church. The last definition was the main reason for the split of the churches. However, Sheptytsky notes, without accepting these truths, the Orthodox Church did not deny them, because such an act as the proclamation of the dogma of faith requires a decision of the Ecumenical Council, which, by their own admission, is not valid.

Of course, A. Sheptytskyy goes on to say, there are other differences: "we do often hear the remark that we are so different in the most basic concepts of Christianity that even if there were not dogmatic divisions that divide us, we would still be divided by the the understandings of Christianity, of the Gospel, of salvation" ${ }^{254}$. Probably not, if only we perceive the church connection not as the establishment of complete unity, but as the unity of differences. "All our notions of Christianity and Godproclaimed Doctrine," A. Sheptytsky writes, "are just a copy of God's vision. There can be so much subjective element in that copy, or so many different definitions of objective science, that people can differ from each other in many very basic quests" 255 . This also applies to ritual differences, which, according to A. Sheptytsky, are of secondary importance, because "faith is more important than ritual" "256.

A. Sheptytsky believes that, despite all the differences, the realization of ecumenical ideas is possible, since the union does not force the unconnected Orthodox to abandon their traditional rite or belief, but it only asks about the addition of the truths of faith, which are in the decisions of the Ecumenical Councils since the X century and till the latest days. However, there are certain conditions that have to be mutually fulfilled on this way. First, one must equally treat religion as religion, and not consider it a political tool for achieving another purpose. Second, there should be a common language, and that language is the Christian worldview. "He, who does not have a Christian worldview, uses a language that we do not understand. For whom, for example, religion is not a matter of worshiping God Almighty, then he means by that word something that I do not know. Those, who do not see in the religion the work of their eternal salvation, the obligation against God,

\footnotetext{
${ }^{254}$ Шептицький Андрей. Листи-послання (1939-1944). Львів, 1991. С. 337-338.

${ }^{255}$ Ibid. C. 338.

${ }^{256}$ Ibid. C. 266.
} 
the Divine Law and danger, when that Law is not fulfilled - for them religion is obviously something different than what it should be for the Christian. For whom Christ is not God and Savior, for whom His Sacraments are not instruments of salvation, not only in the theory of catechism, hidden somewhere in the library, but as real needs and everyday concepts of life, so it is difficult to understand him or her in the case of religion, no matter what religion they belong to" ${ }^{257}$.

Finally, third, the movement to the understanding and unification of the Eastern and Western Churches must be based not only on the unilateral concessions, but it should be also based on the mutual agreement. It cannot be declared from the "top" by church institutions, but it myst be besed on the activity of the believers. A. Sheptytsky most clearly stated this opinion at the Roman Conference of the Eastern Churches in 1923 in his programmatic report on the universal union of the Churches and religious cooperation between East and West. He said next: "Eastern communities came to a Church unity not because of decrees that came from above, but rather because of the ideological movement that moved in them and constantly strengthened, until it shook the inert masses of people. It is clear that in the future only in this way, that is, through ideas, we will be able to reach unity, and only in this way we will be able to persuade the masses and bring them together. We hope and believe that the concept and prejudice of Eastern Christians will change in the direction of moral integrity, which will lead them to the ideas of universality. - And because this can be expected, it is necessary to create a similar ideological movement in the Catholic Church" 258 .

In the deep conviction of Metropolitan Andrew Sheptytsky, an important place in the process of unification of the Western and Eastern Churches belongs to the Greek Catholic Church, which combines the universal faith with the rite, "which is also called the Greek rite, the Byzantine rite and Eastern rite" ${ }^{259}$. Therefore, because of the isolation of the rite, and because the fact thft Greek Catholic Church, together with language and culture, is a factor that distinguishes Ukrainians from their eastern and western neighbors, it must become a link between Catholicism and Orthodoxy, the Western and Eastern worlds in general.

However, in order to fulfill its missionary action, the Greek Catholic Church must also undergo some changes. It is worth discussing this issue in more detail, because during the life of Metropolitan and in the modern theological, scientific, and journalistic literature of some sort, there is an

\footnotetext{
${ }^{257}$ Шептицький Андрей. Листи-послання (1939-1944). Львів, 1991. С. 339.

258 Баран О. Митрополит Андрей Шептицький і його екуменічні ідеї. Украӥнський Історик. 1-4 (120-123). Нью-Йорк - Торонто - Київ - Львів - Мюнхен, 1994.. С. 185.

${ }^{259}$ Шептицький Андрей. Листи-послання (1939-1944). Львів, 1991. С. 266.
} 
accusation of A. Sheptytsky that his ecumenical activity was an attempt to convert the Orthodox into the Catholics. In reality, the activities of Metropolitan combined two directions: first, the struggle for the preservation of the features of the Greek Catholic rite and, secondly, the attempts of spreading the ideas and affairs of the union, not only to the East but also to the West.

This is evidenced by the history itself. XIX century for the Greek Catholic Church was marked by the struggle for the preservation of its national character. Moscophilia from the inside, Latin and Russian influences from the outside led to complete chaos in the rite's affairs. If Moscophilia in the late XIX - early XX century was gradually losing its influence, the processes of Latinization continued to threaten the loss of identity of the Greek Catholic Church. Metropolitan Sheptytsky's first steps were in order to restore the rite's affairs, to return to the true Eastern Orthodox tradition. This question remained the focus of his attention throughout his life.

First of all, A. Sheptytsky tries to find out the internal and external causes of Latinization. "Since the Union of Brest", he writes, "Holy See left us a wide freedom, expressing only the desire that we keep our ordinances and customs unchanged. And we, while exercising that freedom, eventually ceparated in ceremonial practices, because some of our priests adhered to one ritual customs and some adhered to other" ${ }^{\text {"260 }}$.

Such ceparation was exacerbating by the absence of a single center for the publishing of liturgical books. The scattered book publishing led to arbitrary changes and omissions in the liturgical books at the initiative of book publishers, or even the Ordinaries of some eparchies.

The Zamostia Council in 1720 had to restore the unity in ceremonial matters. However, approving the two ceremonial changes, the Council silenced everything else, which meant their toleration. All this contributed to the spread of tendencies towards the convergence of Greek Catholic and Roman Catholic rites.

In addition, as A. Sheptytsky emphasizes, "to our parents... it seemed that they needed, at least through small customs and practices, to get as close as possible to the Latin rite, in order to earn for themselves the opinion of true Catholics in the eyes of the Latins, the closest neighbors, as in the eyes of the Latins from the western parts of Europe and in Rome. This thought pushed many of our priests to receive an unlawful customary from the Latin rite, because it was not approved by the Holy See and even by the church authority in our Church"261.

${ }^{260}$ Баран О. Митрополит Андрей Шептицький і його екуменічні ідеї. Украӥнський Історик. 1-4 (120-123). Нью-Йорк - Торонто - Київ - Львів - Мюнхен, 1994. С. 123.

${ }^{261}$ Шептицький Андрей. Листи-послання (1939-1944). Львів, 1991. С. 154. 
External factors also significantly influenced the spread of the Latinization of the rite. During the counterattack of Polish chauvinism in Halicia, which took place after 1848, the Latinization of church was considered and was used as one of the most effective factors of the spread of Catholicism, and later on, the polonization of the region's population.

Latin tendencies also strengthened the actions of the Russian tsarist authorities aimed at the destruction of the Greek Catholic Church, first in the Belarus, in Polotsk and Viennese eparchies and in Volyn in the 1830s, and then in the Chelm Land in the 1870s. The struggle with the church was carried out here under the slogan "purification of our rite from all Latinizations", and, in fact, it was aimed at the outburst of Russian state orthodoxy and the russification of the population. Therefore, Latinization began to be seen as a means of preserving national identity and defending one's religion. The situation was complicated further by the fact that the prohibition to change ceremonial practices in Eparchy, issued by Holy See after the events in the Chelm Land, was perceived by the proponents of the Latin direction as the full approval and sanctification of the Latin practices of the Greek Catholic rite in general.

The actions of the Russian occupying power in Galicia during the First World War also contributed to the spread of Latinization. This authority, which, according to Hrushevsky, was represented by police and bureaucratic powers, proclaimed the transition to Orthodoxy as one of the most important measures of loyalty of the population. And it did not only proclaim, but also persistently began to implement the official ideology of autocracy by the most violent methods. No wonder the leader of the Cadet Party, P. Miliukov, in 1915 stated: "We have pushed out our dear Ukrainian people with our actions in Galicia and have darkened the clear face of the liberation war" ${ }^{262}$.

Thus, the struggle against Latinization was also difficult because "ceremonial questions were always considered as political and political questions always had a dogmatic coloring. It was not a question of whether such a practice was legitimate, but whether that practice brought us closer to the Russian Church, or vice versa" ${ }^{263}$. At the same time, as Metropolitan notes, often they do not pay attention even to the fact that the Russian Church under the patriarch Nikon underwent ceremonial reforms, during which many valuable parts in the Holy Scripture, that were contained in the the texts of Skaryna and the Ostroh Bible, had been removed.

Overcoming Latinization was not only indispensable for the preservation of the identity of the Greek Catholic Church, but was also a necessary prerequisite for the further development of inter-church unification

262 Заборовський Я. Ю. Митрополит Андрей Шептицький. Нарис про життя і служіння церкві та народові (1865-1944 рр.). Івано-Франківськ, 1995. С. 30.

${ }^{263}$ Шептицький Андрей. Листи-послання (1939-1944). Львів, 1991. С. 155. 
processes. Almost throughout the XIX century, the theologians of the Latin Church have little interest in the problem of uniting the Churches, considering it irrelevant. The neglect of the Eastern Church, neglect of its peculiarities, led to the fact that "when long ago the Ecumenical Bishops in their encyclicals concidered the question of the Eastern rites, and when they always returned to the principle that the Universal church wants to pass on its faith to all the united Churches and the believers, and not the Latin rite (ut omnes catholici fiant, non ut fiant latini) - the theologians, were not very animated by this principle, many of them had a desire that The Church also resisted the unity of the rites, and wanted the Eastern rites to be close as much as possible to the Latin rite" ${ }^{264}$. A. Sheptytsky emphasizes that such an opinion was quite widespread not only among our closest neighbors, but also among many theologians, prelates, priests, bishops of the Western Europe. Much of the Greek Catholic clergy supported the need for rapprochement in religious affairs, even those who had completed their studies at foreign universities, seeing this as a surefire way to create a good opinion about them between Western theologians. For this reason, "who dared to wear a beard, a wide-sleeved cowl, and to hold the ordinances during the Church service, as prescribed in the church books, then he could be easily suspected that he had a tendency to break away from the Universal Church"265.

However, in the last third of the XIX century the situation is radically changing. If earlier Byzantine history, law, art, religion were considered to be of little interest and were hardly explored, now they have begun to arouse the interest of scholars. In Western Europe, there are numerous studies on these issues, and the departments of Byzantinism are opened in the universities. The fall of tsarist power in Russia led to a resurgence of hope for the unification of the Churches and a complete change in the perception of the Eastern Church and its rite among Western theologians. But, unfortunately, these processes had little impact on the situation in the Greek Catholic Church, where Latin trends continued to grow. Therefore, in A. Sheptytsky's deep conviction, only a return to the original liturgical law, the restoration of ceremonial practices and customs, "which would not offend or push away our brothers from us and from the universal faith" 266 , will allow the Greek Catholic Church to fulfill its historic purpose.

Consequently, it is from addressing the internal problems of the Greek Catholic Church that A. Sheptytsky begins his activity towards the union. He kept repeating to his believers that he requires three things: first, to know their faith well, secondly, to know the faith of the Orthodox brothers, and third, to pray for unification. Moreover, he expected the believers to treat the

\footnotetext{
${ }^{264}$ Шептицький Андрей. Листи-послання. Львів, 1991. С. 155.

${ }^{265}$ Ibid. C. 160.

${ }^{266}$ Шептицький Андрей. Листи-послання (1939-1944). Львів, 1991. С. 150.
} 
Orthodox honestly and cordially, he emphasized, referring to the practice of the Holy See, that those who are not unified should not be called schismatics, asked to avoid in the communication with them, "such conversations that would stimulate abandonment of the Orthodox faith or its' renunciation" ${ }^{267}$. But A. Sheptytsky demanded the same attitude towards the Greek Catholic Church from the side of the unconnected Orthodox.

However, the main place in the ecumenical struggle of Metropolitan A. Sheptytsky was occupied by the work on the spreading of the ideas of union and the mutual rapprochement of the Churches. It, like other Metropolitan's affairs, has undergone a significant evolution, in which, of course, it is quite possible to distinguish several stages. The first of them covers the period from the 1880-90's to the beginning of the XX century. During this period, A. Sheptytsky thought that he would be able to achieve church unity in all the expanses of the Russian Empire.

In the Roman decree, which gave A. Sheptytsky the authority of the Metropolitan, it was written that he, like his predecessors, also became Bishop of Kamyanets-Podilsky, along with the dignity of Archbishop of Lviv. The Eparchy of Kamyanets-Podilsky belonged to the Halician Metropolitan since 1807, but its territory was within the Russian Empire. Therefore, A. Sheptytsky addresses a letter to Pope Pius X, in which he questions the possibility of exercising jurisdiction in the territory of the mentioned empire. Pope Pius X confirmed this jurisdiction, noting, however, the need for favorable political circumstances. In his letter of February 1906, the Pope, at the same time as Metropolitan Andrey was named Apostolic Administrator of the Eparchy of Kamyanets-Podilsky, granted A. Sheptytsky authority throughout the Russian Empire. These extraordinary rights and powers were confirmed by Pope Pius X (in 1909, 1910 and 1914), by Benedict XV and by Pius XI. For the sake of caution before the Russian government, full ownership was kept secret and was known only to the Pope and the Metropolitan.

However, certain opportunities for the work on union in the territory of the empire emerged only after the revolution of 1905, when freedom of conscience was established in Russia. In the first half of 1907, A. Sheptytsky presented to Pope Pius X his plans to organize a Catholic church in the territories of Ukraine, Belarus and Russia. It was a about consecrating priests and bishops of the Greek Catholic rite, to which the Pope agreed. In the autumn of 1907, A. Sheptytsky makes a secret trip through the territory of the Russian Empire under the name of Dr. Olesnytsky. This trip was fraught with great risk because Sheptytsky could be seized and charged with espionage, especially after someone had stolen his illegal passport on the

${ }^{267}$ Ibid. C. 79. 
way. Metropolitan visited Vilno, Minsk, Slutsk, Moscow, and St. Petersburg. In Belarus, A. Sheptytsky conducted secret negotiations with the local intelligentsia and the university youth and found many supporters of the church unification. And in Russia, with the help of some Old Believers, the pro-Catholic intellectuals and the clergy of the Russian Orthodox Church, committed to the Catholic Church, A. Sheptytsky established several secret Greek-Catholic congregations ${ }^{268}$. He also appointed Fr. Alexei Zerchaninov as a General of the Kamyanets-Podilsky eparchy and a pastor for Catholics of the Byzantine rite in Russia. Unfortunately, during this trip, A. Sheptytsky was unable to visit Ukraine, because Austrian government circles feared that the tsar's secret service could catch him and send him to Siberia ${ }^{269}$. Metropolitan was able to visit Kyiv only in 1912. Here he sent a memorial service for Taras Shevchenko in the church of St. Nicholas and delivered a patriotic sermon about Great Kobzar. In order to fully appreciate the significance of this act, it should be mentioned that in those days the tsarist government forbade public celebrations of Shevchenko's anniversaries.

In 1906, the Brotherhood of Prayer of the Cyril and Methodius Apostolate in Moravia put forward the idea of the annual congresses of the Slavic peoples and the Slavic Churches, Catholic and Orthodox, at the tomb of St. Methodius in Velegrad for the purpose of mutual knowledge and cooperation in the unification of the Christian world. Having learned about this idea of the Moravian clergy, A. Sheptytsky supported it fervently and soon, according to the Duke von Otrahsen, became the soul of this idea ${ }^{270}$. Thanks to its activities, the Congress of Velegrad became a kind of flag of church unity. They substantiated the thesis of the equality of ordinances in the Ecumenical Church, created a solid nucleus of the ecumenical movement, which sincerely desired church unity, and put this movement on solid theological and dogmatic foundations.

The first congress in Velehrad took place on July 24-27, 1907. Its program included reports from all of the best theologians and scholars of the East and West, which sparked lively discussions. Metropolitan A. Sheptytsky presided at this congress and in his opening address outlined a number of issues that, in his opinion, should have been raised at the Congresses of Velehrad: "1) scientific, theological and historical questions about both Churches and clarifications of the basics of both Churches doctrines, 2) practical issues such as: possible elimination of existing misunderstandings and gossips between Catholics and Orthodox, and

\footnotetext{
${ }^{268}$ Seе.: Кравченюк О. Велетень з Святоюрської гори. Йорктаун, 1963. С. 16-20.

${ }^{269}$ Ibid.

${ }^{270}$ Кравченюк О. Велетень з Святоюрської гори. Йорктаун, 1963. С. 20.
} 
establishment of friendly relations on a purely scientific basis between Catholic and Orthodox theologians"271.

At the second congress in 1907, Metropolitan A. Sheptytsky was again elected a chairman and he proclaimed a program report, in which he thoroughly substantiated ecumenical ideas and outlined his views on possible ways of their realization. Unfortunately, Metropolitan could not attend the third congress, because in July 1911 he was bedridden with illness, but the congress did not forget about him and elected an honorary chairman. Due to the First World War, the periodicity of the congresses was broken and the fourth Congress was held only in 1924. However, Metropolitan could not attend at this Congress because the chauvinistic authorities of Poland did not issue visas to either him or J. Slipyi.

The last Congress of Velehrad, at which A. Sheptytsky was present and delivered the report, the fifth in number, took place in 1927. At the following congresses - VI in 1932 and VII in 1936 - delegation of the UGCC included bishops who, in their activities, relied on the ecumenical ideas of Metropolitan A. Sheptytsky. Unfortunately, the VII Congress, appointed in 1939, did not take place due to the outbreak of World War II. However, it is difficult to overestimate the significance of the Congresses of Velehrad and the work A. Sheptytsky did there.

Metropolitan paid great attention to the communications with the Roman Catholic clergy and the intellectuals of Galicia and Volyn at the Union Conferences in Pinsk, initiated by the Holy Conference for the Eastern Churches. Unlike the congresses in Velehrad, the conferences in Pinsk were practical. There were six in total: in 1930, 1931, 1932, 1933, 1935 and 1937.

In December 1936, again on the initiative of Metropolitan A. Sheptytsky, the fifth Union Congress was convened in Lviv. For three days, more than 150 participants were present in the walls of the Theological Academy - mostly clergy from three eparchies of Galicia. Rector of the Theological Academy Fr. J. Slipyj, on the instructions of A. Sheptytsky and relying on his ecumenical ideas, made a Main report, titled "A Look at the United and Not United Churches of the East and the Dogmatic Differences Between Them". The purpose of the report was to "look closely at the Eastern Churches, of which we know, unfortunately, very little and with whom we maintain very weak links, even though we have inherited Christ's faith, rite and culture from them. Undoubtedly, this approach will broaden our knowledge and will place the case of union in its original breadth, allowing us to make some necessary conclusions. We, fascinated by the splendor and power of Western culture, did not pay much

${ }^{271}$ Ibid. C. 21-22. 
attention to the ancient East and therefore lost our perspective on the area and the history in which we grew up" ${ }^{272}$.

Having considered in the report the main groups of the Christian Churches of the East, Fr. J. Slipyi, following A. Sheptytsky, sharply opposes the attempts of the Latinization of the Eastern Churches, indicating that "the cognition of the East, the love and preservation of its traditions - this is the path to unity, as indicated by the Popes. The United Churches must keep the Evidence faithfully in order not to be separated from their unrelated brethren in the rites and scriptures of their Church. The fewer accusations, biases and differences, the faster the rapprochement will become.

Theologians do not dare to destroy, as Latin theologians themselves rightly claim, what oriental Christianity created in the rite and discipline. Because they would break the valuable heritage of the Church, which is neither Greek nor Latin, but it is Catholic" ${ }^{\text {"273 }}$.

Josyf Slipyi emphasized the special role of the Ukrainian Church in the ecumenical movement, initiated by Metropolitan Andrey Sheptytsky, its mission among the Churches of the Christian East. Thus, Metropolitan had a worthy assistant and a follower in his person.

At the same time, according to Ukrainian researchers (S. Baran, V. Doroshenko), at the beginning of his activity on unification A. Sheptytsky felt an acute shortage of educated staff capable of working on the rapprochement of Western and Eastern Christian churches. Therefore, in addition to sending the most gifted seminarians to theological studies to the best religious institutions in Europe, Metropolitan restores the activity of the ancient - since the XI century - the rank of the fathers of the Studites. He founded the first monastery for them in 1903 in the suburb of Lviv Sknyliv. It is important to note that the rank adhered not only to the Eastern rite, but also to the rules of monastic life. In 1905, A. Sheptytsky developed a new monastic charter for the rank - Tipikon, which was approved by all bishops of the archdiocese the following year. Archimandrite of the Rank was Metropolitan himself. In 1919, the monastery was moved to Unev near Przemysl. In 1939, the Rank consisted of 132 monks and nearly 50 nuns.

For the same purpose, Metropolitan A. Sheptytsky invites the Fathers of the Belgian Order of the Redemptorists for missionary work in Galicia in 1913. In order to act more successfully, the monks accepted the Eastern rite and subsequently created an eastern branch of the Order. In 1938, after 23 years of activity in the territory of Galicia, the Order numbered 50 priests,

${ }^{272}$ Гринів О. Йосиф Сліпий як історик, філософ, педагог. Львів, 1994. С. 28.

${ }^{273}$ Ibid. C. 29. 
20 students of theology, 34 brothers-assistant, 14 novices and candidates, and 115 students of the Little Seminary ${ }^{274}$.

However, Metropolitan's hopes that these two monastic congregations would have a significant impact on the revival of the processes of unification were not fulfilled, since their activities were mainly limited to the Lviv Archdiocese.

World War I hit a hard blow to the ecumenical ideas of A. Sheptytsky. The outrageous behavior of the Russian occupation administration in Galicia has already been discussed. It also paid its "attention" to Metropolitan himself. On September 3, 1914, Russian troops captured Lviv. The Orthodox Archbishop of Zhytomyr and Volyn Evlogiy arrived with the Russian army. Having a frankly anti-Ukrainian position, he saw a great danger to his plans in the speeches of Metropolitan Andrey against the violent introduction of the Russian Orthodox Church, his activity on unification, and, therefore, he insisted on the arrest of A. Sheptytsky ${ }^{275}$. In this he was supported by the tsarist governor of Galicia and Bukovyna, Count Y. Bobrynsky. As the fullness of power was in their hands, the fate of Metropolitan was predetermined. They needed only a formal occasion. On Sunday, September 6, 1914, A. Sheptytsky had a service in the Church of the Assumption of the Blessed Virgin Mary in Lviv, after which, as always, he delivered a short sermon. In it, Metropolitan asked to pray for millions of soldiers on both sides of the front, described the terrible state of Galicia, which became an arena for war battles from the first days of the war, called for mutual understanding between Galicians and Russians. "We must know ourselves", he said, "though in many respects we are like ourselves. They have a service the same as ours, they call themselves "Orthodox" and we are "Orthodox". Our Orthodoxy is ecclesiastical, their Orthodoxy is the state Orthodoxy, that is to say, a "treasury" one, which means that they base their Orthodoxy on the state power, we derive that power from the unity with the Holy Catholic Church, through which the grace of God emerges and in which there is a true source of salvation"

It was these words that led to the arrest of Metropolitan on September 19, 1914 and to his the exile first to Kyiv and then to Russia: to Nizhny Novgorod, Kursk, Suzdal, Yaroslavl. In Suzdal, A. Sheptytsky was imprisoned in a monastery-prison. The conditions of imprisonment were

274 Заборовський Я. Ю. Митрополит Андрей Шептицький. Нарис про життя i служіння церкві та народові (1865-1944 рр.). Івано-Франківськ, 1995. С. 24-25.

275 Often the fate is very bizarre - it is good or cruel. In 1919, escaping from the Bolsheviks, the Metropolitan of Kiev Anatoly Khrapovytsky and Archbishop Evlogiy Georgievsky (that same) arrived and were arrested by the Polish authorities. A. Sheptytsky not only sought their release, but also granted them, as well as Bishop Alexei Dorodnitsyn, a shelter in his ward for any term they needed.

${ }^{276}$ Світильник Істини. Торонто - Чикаго, 1976. Т. 2. С. 133-134. 
very harsh: the low cell did not allow him to stand in full height, Metropolitan was forbidden to talk, to write letters, to leave the cell and even the church.

In defense of the "tsarist prisoner", progressive figures of Russia, including the writer V.G. Korolenko, the European press, the Austrian and German governments, the Spanish king, the European aristocratic nobility, the Apostolic See, made a protest. Following the retreat of the tsarist troops, the Lviv community twice appealed to Nikolai II to release Metropolitan, because there was no need in hostages any more. However, months, years passed, and there was no answer.

Only in March I917, at the request of Nikon, Metropolitan of Krasnoyarsk, the government of O. Kerensky finally released A. Sheptytsky from imprisonment. Nikon demanded: “...to release the great sufferer Metropolitan Andrey Sheptytsky, who in the difficult moment for his peoples did not leave them, but remained with them, and for that he was imprisoned, which disgraced the whole Russia to the world"277.

However, even under such unfavorable conditions, A. Sheptytsky tried to use his captivity to attempt to register the Greek Catholic Church in Ukraine and Russia. During his brief stay in Kyiv in 1914, Sheptytsky dedicated Fr. Joseph Botsian, Rector of Lviv Theological Seminary as Bishop of Lutsk. After his release, at the end of May 1917, Metropolitan convened a Synod of the Russian Catholic Church in Petrograd, consisting of 8 Orthodox priests, during which he nominated Fr. Leonid Fedorov as his exarch of the whole of Russia, and two other exarchs were appointed for Belarus and Ukraine, in particular, Fr. Volodymyr Hromnytsky - as an exarch for Eastern Ukraine, and Fr. Mykhailo Tsehelsky - as the General Vicar. The newly created structure of the Greek Catholic Church in the East existed until the arrivals of the Bolshevik power, when it was liquidated, like all other churches.

During his forced stay in Russia, A. Sheptytsky had the opportunity to get acquainted with the upbringing, the structure of the Russian Orthodox Church, to feel its prejudiced attitude towards the West. Here he also realized that the West did not know the East sufficiently. Therefore, in order to increase and unite the Churches, the West must study not only Eastern theology, but also the psychology and ideology of Eastern Christianity. In his view, several institutions had to be set up in the West for an in-depth study of Eastern Christianity.

On the advice of A. Sheptytsky, Pope Benedict XV created the Roman Oriental Institute and handed it over to Benedictines. However, Metropolitan Andrey was not satisfied with the establishment of only one institute. He

277 Заборовський Я. Ю. Митрополит Андрей Шептицький. Нарис про життя і служіння церкві та народові (1865-1944 рр.). Івано-Франківськ, 1995. С. 28. 
personally addressed the Benedictines to establish their own institution or the center for oriental studies. This led to appearance of the Eastern Benedictine Monastery in Amei. In response to the formation of this monastery, the Dominicans set up a "True" - an Orthodox Studies Center in Paris; and in the Netherlands Kyr Andrey started personally the "Apostolate of the Unification" to learn about the East. All these institutions began to publish scientific journals. Due to the efforts of A. Sheptytsky, ecumenical ideas also spread in Spain - a review "Obza del oriente Kristiano" was published here - and in England, where the journal "The Eastern Churches Quaterly" began to be published.

However, A. Sheptytsky did not limit himself only to organizational activities. Being in Rome in 1921-22, before and after his great pastoral journey, during which he visited the Ukrainian diaspora in France, Belgium, Holland, England, Canada, USA, Brazil, Argentina, A. Sheptytsky not only met Pope Benedict XV and Pius XI personally, described them the terrible state of Galicia under Polish occupation and told them about his plans, but he also gave several public lectures on the idea and missionary capabilities of the union.

For the same purpose, that is, to encourage and prepare the Galician clergy for missionary work in the East, on December 16, 1923, Metropolitan founded the Theological and Scientific Society. At the scientific sessions of the Society, up to 1939, 25 reports were listened, most of them ecumenical.

In February 1928, Metropolitan opened the Greek Catholic Theological Academy in Lviv, which was to become "the foundation of the spiritual revival of Our People and the preparation of our Holy Church to fulfill the great mission in the vineyard of Christ, on Ukrainian Land and among the peoples of Eastern Europe..." ${ }^{278}$, to serve the case of the religious union between East and West. A. Sheptytsky also directed other educational institutions of the Greek Catholic Church to accomplish this task.

It is clear that during the period between the two world wars, Metropolitan's major efforts were directed towards the restoration of the Greek Catholic parish in Galicia, which upon his return from exile he found in complete ruin. This work took place in the difficult conditions of the advancement of Polish chauvinism, which could not bypass Metropolitan himself. Repeated arrests, systematic harassment in the press, both Polish and "homegrown" - radical, pro-communist, as well as in the autocephalous periodicity of Canada and the USA, constant slanders on A. Sheptytsky from the top of the Polish clergy to the Apostolic See, and to Pope personally such was an atmosphere in which Metropolitan had to act. However, the

278 Греко-Католицька Богословська Академія у Львові в другому трьохліттю свого існування (1931-1934). Львів, 1934. С. 28. 
very fact that $\mathrm{A}$. Sheptytsky was almost constantly in the spotlight testifies to the importance of his activity and undeniable personal authority.

However, as can be seen from the above, Metropolitan Andrey Sheptytsky did not leave ecumenical issues even in this situation, although the conditions for the practical realization of his plans on unification worsened.

Metropolitan A. Sheptytsky's pastoral letter of August 2, 1938, "In the case of the Chelm Land", which referred to the protection of the Orthodox Church in the Ukrainian lands that were part of Poland, caused the great public resonance and had positive consequences. In this letter addressed to the Greek-Catholic clergy, Metropolitan sharply condemns the brutal action of the Polish government, which, with the help of administrative and police factors, pursued a policy of banning Orthodox churches in the Chelm Land and forcing the Orthodox to convert to Catholicism.

Destruction of the Orthodox churches led by starosts of the povits and by Polish state police began in the winter of 1937 and acquired a large size in the spring of 1938. It was held under the slogans of "equalization of historical injustices" and "destruction of traces of captivity". In the Chelm Land and Pidliashia region, the Poles out of 389 Orthodox churches turned 149 into Roman Catholic churches, and they completely destroyed 189. There were unique monuments of church architecture among the destroyed churches. At the same time, the cemeteries near the churches were often destroyed, the remains of the Orthodox were thrown out of the graves with the greatest abuse, the religious and national feelings of the Orthodox believers were ridiculed.

In his message, Metropolitan Andrey stood up for the protection of "persecuted brothers, of our not-united Orthodox Christians of Volyn, Chelm Land, Pidliashia and Polissia"279. After listing the devastation caused by this action, Metropolitan of Lviv and Galicia states: "The whole Orthodox population of Poland is alarmed. The population of the Chelm Land is wounded into the most holy and noblest of feelings. And all those, who are united with the Universal Church in the East, are feeling sorry for the blow, that a case of the union...

The events in the Chelm Land obliterate in the souls of the Orthodox, our not-united brothers and sisters, the very idea of the possibility of union, present the Ecumenical Church as hostile and dangerous to the Orthodox people. In the eyes of the multi-million population of Poland, the Apostolic Capital is represented as an accessory in the case of destruction. A new abyss is opening up between East and West" ${ }^{\prime 280}$.

${ }^{279}$ Науковий збірник УВУ. Т. 15. Мюнхен, 1992. С. 49.

${ }^{280}$ Науковий збірник УВУ. Т. 15. Мюнхен, 1992. С. 49. 
According to the author of the message, the anti-Christian acts and facts of religious persecution are a triumph for the enemies of the Church - the Masons, who have caused a "moral blow to the very idea of uniting the Churches and to the authority of the Universal Church and the Apostolic Capital" ${ }^{\prime 281}$.

The message was published on the front page of the newspaper "Dilo" (dated August 23, 1938) and was immediately banned by Polish censorship. However, the Polish police could not confiscate the circulation of the newspaper: anticipating this, the printing and editorial staff was able to get ahead of the police and take out and distribute the entire printing of the issue. Sheptytsky's protest became widely known not only in Poland but throughout Europe. The Vatican intervened, and the violent Catholicization of the Orthodox Ukrainian population was stopped.

The beginning of World War II, the annexation of Western Ukraine and Western Belarus to the USSR, in accordance with the Ribbentrop-Molotov Pact, revived the hopes of A. Sheptytsky to carry out an ecumenical action in the territory of the whole East. As early as September 7, 1939, he convened a secret meeting of the Exarchs to discuss his plans about union. Using the powers granted to him by Pope Pius X and confirmed by his successors, Metropolitan Sheptytsky on October 9, 1939 created four new exarchates, covering the entire Soviet Union: exarchate of Volyn and Chelm Land, headed by bishop Mykola Chernetsky; exarchate for Belarus (Father Anthony Nemantsevych); exarchate of Great Russia and Siberia (Father Abbot Clementiy Sheptytsky); exarchate for Great Ukraine (Dnieper Ukraine) (Archbishop Josyf Slipyi) ${ }^{282}$. At the same time, on October 10, 1939, Metropolitan writes a letter to Pope Pius XII asking him to confirm the authority given to him by Pope Pius $\mathrm{X}$ and permission to consecrate Archbishop Fr. Josyf Slipyi as his helper with a right of succession. Two weeks later, the Congregation for the Eastern Church fulfilled the request of Metropolitan. However, his new powers canceled the previous ones. Therefore, on October 12, 1940, Metropolitan Andrey informed the four exarchs that he no longer had even the power to accept their release from the the duties and that he leaves them with a conscientious choice of further course of action.

A. Sheptytsky connects certain new prospects for his traditional work on the unification of the Churches with the advance of German troops and the occupation of Ukraine, Belarus and a part of Russia. He was quickly convinced, however, that the occupation policy of the Third Reich in the East would not make it possible to carry out an action on unification in full.

\footnotetext{
${ }^{281}$ Ibid. C. 50.

282 See: Артикули для започаткування процесу беатифікації і канонізації Слуги Божого Андрея Шептицького. Рим, 1958. С. 26.
} 
The Germans forbade the missionary activities of Catholic priests; they arrested and executed Exarch Nemantsevych and many lower-ranking clergy...

That is why, from the end of 1941 a new stage of A. Sheptytsky's activity on unification begins: from now on his Christian "oikumen" is restricted to the territories of Ukraine. He directs all his efforts towards rapprochement and the future unification of the Ukrainian Orthodox and Catholic churches, because "no people suffered in education so much from the unhappy separation of the Churches as the Ukrainian people"283. According to A. Sheptytsky, church unity is indispensable because of three main considerations. First, such unity, he believed, would be an important factor in the union of Ukraine with the West, because in a cultural and spiritual sense, Ukrainians belong to the European, rather than Euro-Asian (or Asian-European, according to the apt expression of the famous poet M. Brodsky) continent. Therefore, A. Sheptytsky writes, since ancient times, "in Ukraine, as today, smarter people have seen... that the future of the people is in conjunction with the West, because only this union is able to distinguish our nation from the neighbors of the north and northwest. They understood that only a religious connection could secure a future connection with the culture of the West, because the West would not recognize us, if we will be for a long time religiously connected with Asia. And we have no other way of getting connections with Western culture, except with the help of some direct connection that would jump over our closest neighbors from the West. And such a connection can only be a religious connection"284.

Secondly, the union with the Universal Church would become a model of national unity, of which the Ukrainian people dreamed for centuries. "In church unity," A. Sheptytsky noted, "we will have not only strength but also an example of what national unity should look like. From the structure of a single, holy, universal apostolic Church, we will be able to learn and attest to what should be the sovereign leading unity of the Ukrainian people"285.

Finally, thirdly, the religious and national processes of unity of the people are interconnected and interdependent and do not exist without one another. According to A. Sheptytsky, "Ukrainians are faced with such an absolute need to do everything in their power to achieve national unity, without which all our ideals and works for church unity will be dispelled, that is again one of the most important conditions of national unity" 286 .

However, the real state of affairs at the time was disappointing: the war sharpened religious, national, and political contradictions. "There is no need

\footnotetext{
${ }^{283}$ Шептицький Андрей. Листи-послання (1939-1944). Львів, 1991. С. 76.

${ }^{284}$ Шептицький Андрей. Листи-послання (1939-1944). Львів, 1991. С. 356.

${ }^{285}$ Гриньох І. Слуга Божий Андрей. Благовісник Сдности. Мюнхен, 1961. С. 198.

${ }^{286}$ Шептицький Андрей. За одність Церкви. Логос. 1952. Т. 3. № 3. С. 163.
} 
in other enemies", A. Sheptytsky notes with pain and bitterness, "when Ukrainians themselves are enemies of Ukraine, who hate each other and do not even feel ashamed of that hatred! As long as there is no Christian unity between us, for so long will our weakest opponent be stronger than we are! As long as Ukrainians in their national affairs will be remembered more for their own individual good, for so long the common cause will not be able to develop successfully. Because there will be no common cause, because it will not be in the minds and in the conscience of the people!"287.

Therefore, the main task that Metropolitan set before the clergy and believers is next: "There is no greater sign for our people today, as unity, and no more important work for our clergy than the work on the national and Christian unity of the people. These two works are complementary" ${ }^{\text {"288 }}$. Such activity, according to A. Sheptytsky, should not only be considered as one of the main manifestations of the moral obligation of the love of God, which is embodied in Christian love for one's neighbor, but it also should be considered as the most important element of Christian patriotism. This is not a political, not a pagan patriotism, in which "love to ours is received with the hatred of all others"289. The essence of Christian patriotism, according to A. Sheptytsky, is that, while loving all peoples of the world with the love of one's neighbor, own people, the Ukrainian people, must be loved with a Christian love more than other peoples, and we must be prepared to give our people a lifetime's work, and if it is needful - the life itself.

Metropolitan Andrey Sheptytsky conducts his activities, aimed at the formation of a unified Ukrainian Church, in two directions. On the one hand, he does not lose hope in the more thorough support of his plans on unification by the Apostolic See. With this aim, on October 29, 1941, A. Sheptytsky wrote an information letter to the Pope. In a letter, written in French, he presents an analysis of the situation of the Church in Ukraine under the Bolshevik, and subsequently German occupation, and raises the question of "the return to the Church of Christ of millions of Eastern believers, still excommunicated from unity" 290 . This requires priests, but the Germans forbid both Greek Catholics and Orthodox from Volyn and Chelm Land to do missionary work in the Dnieper Ukraine. Among the intelligentsia in Ukraine, there are also people who are sympathetic to the Greek Catholic Church; they need only a bishop who is willing to promote church unity. "If it was possible for us to send one bishop to Kyiv," A. Sheptytsky writes, "it seems that with his hard work and caution, he could take the lead of the movement and bring at least a healthy majority of the

\footnotetext{
${ }^{287}$ Шептицький Андрей. Листи-послання (1939-1944). Львів, 1991. С. 230.

${ }^{288}$ Ibid. C. 408.

${ }^{289}$ Ibid. C. 413.

${ }^{290}$ Kozlevskij C. Metropolite Andre Szeptyckyj. 1865-1944. Rome, 1964. P. 375.
} 
whole people to Catholic unity. We cannot send anyone out because of a formal ban by the Germans, but if there were some pious and reasonable people among Orthodox Ukrainians that could fulfill this task of spreading church unity throughout the country, the Catholic Church could have won" 291 .

Therefore, Metropolitan once again asks Pope Pius XII to confirm the authority given to him by Pope Pius X, and to confirm the already named exarchs, which will help him in his work in the East. On November 22, 1941, the Pope confirmed the exarchs and named Metropolitan Andrey as a delegate to the Apostolic See. However, the Pope did not dare to grant Metropolitan's request for the ordination of several bishops among Orthodox converts.

On the other hand, at the same time as he wrote the letter to Pope Pius XII, Metropolitan Sheptytsky appealed directly to Orthodox bishops and later to the Ukrainian Orthodox believers from inteligentsia, with letters calling for ecclesiastical and national unity. These letters were partly printed in the Ukrainian press of that time, and then published in a collection of documents "In the Case of Understanding" (left unfinished), with the preface by Metropolitan, with the responses to his letters, and with A. Sheptytsky's answers to his opponents. The following documents are in chronological order:

1. Letter from Metropolitan Sheptytsky to I. Ohienko, Archbishop of Chelm, dated October 21, 1941;

2. An open letter from A. Sheptytsky to the Warsaw Orthodox Metropolitan Dionysius of December 30, 1941;

3. Letter from Metropolitan Andrey to Orthodox Bishops in Ukraine and the Ukrainian lands of December 30, 1941;

4. Letter from Metropolitan to the Ukrainian Orthodox believers from inteligentsia of March 3, 1942

A. Sheptytsky was acquainted with professor I. Ohienko - a well-known specialist in the history of Ukrainian culture and the Church, Minister of Education within the Government of the UPR (from January to May 1919), the founder and first rector of Kamyanets-Podilsky University -since the 1920s, when I.Ohienko as an emiagrant arrived in Lviv and found refuge in Metropolitan's premises. Recalling the old acquaintance and friendship, Metropolitan congratulated Hilarion on his recent consecration, wished him to restore "St. Volodymyr's and Metropolitan Hilarion's faith" ${ }^{292}$; asked to clear the Ukrainian Orthodox Church from non-canonical, harmful, forcibly

\footnotetext{
291 Жуковський А. Митрополит Андрей Шептицький і православ'я. Науковий Збірник Украӥнського Вільного Університету. Мюнхен. 1992. Т. 15. С. 54.

292 Баран С. Митрополит Андрей Шептицький. Життя і творчість. Мюнхен, 1947. С. 123.
} 
imposed institutions or laws, and, above all, from the Moscow intolerance and anxiety that marked all Moscow Orthodoxy.

Archbishop Hilarion replied to Metropolitan by letter dated November 14, 1941. The main point is that the rapprochement between the two Ukrainian Churches will be possible when not only the Ukrainian Orthodox Church is cleansed of Moscow's influence, but also the Greek Catholic Church will be rid of alien Latin additions. Then "both Ukrainian Churches will come closer to each other like two sisters" $" 293$.

An open letter from A. Sheptytsky to the Orthodox Metropolitan of Warsaw Dionysius was published, despite the prohibition of German occupying power, in the "Krakiwski Visty" of February 15, 1942. In it, Metropolitan proposed a broad program of action to bring the Churches closer together. The reply to this letter, as well as to A. Sheptytsky's appeal to the Orthodox Archdiocese, which will be discussed later, was given by the Council of the Orthodox Church of the Governor-General, which took place on May 27, 1942, and it stated unequivocally: "We are delighted to welcome the Greek Catholic brothers in our Orthodox Church"294. This decision was prepared by Hilarion Ohienko, and Metropolitan Dionysius Valedynsky and Archbishop Palladium Vydybida-Rudenko also participated in the Council, the latter considering the decision to be too sharp. Naturally, ecumenical dialogue could not be reached at such a level and with such a tone.

Central place in Metropolitan Andrey's action on the rapprochement of the Ukrainian Churches takes the open letter "To all the Most Reverend and Blessed Orthodox Bishops in Ukraine and the Ukrainian lands", which was written on December 30, 1941 and published in the diary "Krakiwski Visti" on February 15, 1942. In this small message, A. Sheptytsky closely links religious affairs with Ukrainian national affairs. "To reach our national ideals," he writes, "we need unity... Among the differentiations that divide Ukrainians, religious affairs in which we are so divided take not the last place. And, of course, religious unity would be a powerful impetus for national unity. So, I think, every Ukrainian patriot must do everything he can to achieve such religious unity"295. Such unity, according to A. Sheptytsky, is possible, because the cases that divide the Churches happened a long time ago. These were disputes between the Greeks and Latins, between the traditions learned from the Greek and Moscow churches. However, there are also some prerequisites for a union, namely: a common desire for reconciliation, that all people pray for unity, and finally, concessions are needed from both sides, elimination of all that impedes union. "Therefore, it

${ }^{293}$ Ibid. C. 126.

294 Ленцик В. Ідея Церковної Єдности у Митрополита Шептицького. Богословія. Рим, 1971. T. 35. C. 175-201.

${ }^{295}$ Шептицький Андрей. Листи-послання (1939-1944). Львів, 1991. С. 339. 
will surely be necessary for us to express our sincere thoughts and to openly discuss all the life and theological affairs connected with the union of the Churches, to seek a way to a union" ${ }^{, 296}$. This letter was an invitation to such an open and objective dialogue.

There were few responses to Metropolitan's message. In his letter of March 1, 1942, Palladium, Archbishop of Krakow and Lemkivshchyna states that A. Sheptytsky's appeal "to the Orthodox Ukrainian Hierarchy is what our Church has been expecting for more than 300 years... The discord, that was artificially largerly implemented by the enemies of the Ukrainian Church and the Ukrainian people, must be stopped"297. However, in doing so, he offers his vision of the path of uniting the Churches: "With the knowledge of our Kiriarkh, I have the honor to announce that from the side of the Orthodox Church, we will endeavor to remove all obstacles to the great case of unification, which will be based on returning to the state, that we had before the official collapse of the Orthodox Ukrainian Church in the 16th century ${ }^{9298}$. Obviously, this was in fact a call for the elimination of the Greek Catholic Church and the return to the pre-union status.

Olexiy (Alexei) Hromadsky, Metropolitan of Volyn and Zhytomyr, Exarch of the Ukrainian Autonomous Orthodox Church, remaining in the jurisdiction of the Moscow Patriarchate, in a letter dated April 1942, agrees, factually, with Metropolitan Andrey's idea of unity, but expresses doubts abouth the possibility of its implementation. "...Theoretically, I fully conjecture our union," he writes, "because nothing can prevent that in thought, but practically this combination could be realized only when there is no sin and damage to human nature" ${ }^{299}$. According to him, the obstacles to unification not only lie in the ages, but they also find nourishment in the present, they are eternal. "History, politics, selfishness, individualism and many different isms, from which so much misery on earth, these are obstacles that will probably not be overcome until the end of the world, and they will not allow the union of Christians with each other on earth",300. Pointing to the difficulties that he encountered in trying to establish cooperation between the Autonomous Orthodox Church and the Ukrainian Autocephalous Orthodox Church, Fr. Olexiy thought that “...the difference in religious views may be needed on earth, because it is not for nothing that they say that beauty lies in diversity" ${ }^{301}$.

\footnotetext{
${ }^{296}$ Ibid. C. 340.

${ }^{297}$ Ibid.

${ }^{298}$ Шептицький Андрей. Листи-послання (1939-1944). Львів, 1991. С. 343.

${ }^{299}$ Ibid. C. 345.

${ }^{300}$ Ibid. C. 344.

${ }^{301}$ Ibid.
} 
Painful for Metropolitan A. Sheptytsky was the silence of the bishops of the Ukrainian Autocephalous Orthodox Church, which formed itself under the direction of Metropolitan Polikarp Sikorsky and spread its activity in the territory of the Dnieper Ukraine, in the so-called Reichskommissariat Ukraine.

An open letter of A. Sheptytsky to the Ukrainian Orthodox believers of March 3, 1942 was an addition to Metropolitan's message to Orthodox Archiereus. In it, Metropolitan addresses the representatives of Ukrainian science, literature, art, public figures, as well as patriotic clergy, whom he regards as a leading section in society that also has a strong voice in church affairs.

The letter to intelligentsia specifies Metropolitan's plans of unification and indicates which ways to complete unity should be chosen. First of all, A. Sheptytsky explains his personal condition: he cannot become a Metropolitan of Kyiv as a Greek Catholic. In addition, he has neither desire nor physical fitness because of his age and illness. According to him, "Metropolitan of Kyiv should be chosen from Orthodox or Autocephalous Bishops or priests. If he was united with the Universal Church, we, all Greek Catholics, would be subject to him and I would be the first to gladly submit to his supreme power" ${ }^{302}$. Writing this letter, A. Sheptytsky emphasizes that he has no personal interest and will only fulfill the duty of the Ukrainian patriot. Metropolitan is aware that the complete unity of Greek Catholic and Ukrainian Orthodox denominations is a matter of the very far future. Such unity would only be possible after the long efforts to bring the Churches closer together and to know each other, which in turn is necessary to achieve national unity. Future unity should be pursued through reconciliation, while eliminating mutual misunderstandings between Ukrainians and between Ukrainian denominations. A. Sheptytsky particularly emphasizes that union with the Universal Church does not require renunciation of the customs, giving up the rite of the Ukrainian Orthodox Church, since the difference between Greek Catholics and Ukrainian Orthodox in these matters is very small. Asking the Ukrainian religious intelligentsia to actively work on interfaith spread, A. Sheptytsky notes that even if this work does not lead to full unification, it will still be of great benefit to the Ukrainian people, because it will lead to national unity.

Metropolitan's letter to the Ukrainian intelligentsia received more responses than his appeal to Orthodox bishops. Some of them were positive, others were polemical and with a negative attitude to the proposals of unification, with accusations of the Apostolic See of disrespectful attitude not only to the Orthodox but also to the Greek Catholic Church. Even the

302 Шептицький Андрей. Листи-послання (1939-1944). Львів, 1991. С. 341. 
fact that A. Sheptytsky himself, despite his undisputed services to the Church, was not proclaimed a cardinal, was cited as proof of the latter. Only the "Letter to His Eminence Metropolitan Andrey Sheptytsky", dated April 1942, was published by some Ukrainian figures from Prague and Warsaw, old emigrants. This letter, written in a polemical tone, strongly condemns the historical aspect of the Union and the Catholic Church. The authors of the candid letter regard the Church Union as one of the saddest days of the Ukrainian past, which can be compared with the times of serfdom. In their view, all the epic and historical literature in which Zaporizhia Sich appears in one role or another is an evidence of this. According to the authors of this letter, no efforts towards union are directed at the unification of the Greek Catholic and Orthodox Church, but at the annexation of the Ukrainian Orthodox Church to the Roman Catholic Church, which the Polish Catholicity in Eastern Europe has always represented. "How it represented the Roman Church," they write, "is witnessed by many monuments of the Christophile polish clergy - destroyed, closed and converted into Polish kosciols the Orthodox Churches in the Chelm Land and Volyn in 1937$38^{\prime 303}$. Moreover, this destruction was carried out on the tolerance of the Roman Curia, which, through the Warsaw Nuncio, even advised Metropolitan A. Sheptytsky to appease the defense of not-united Orthodox.

Protecting themselves from criticism that "Ukrainian Orthodoxy has too much Moscow appeal", the authors of the letter argue that it will be easier to get rid of it than for the Greek Catholic Church to get rid of the influence of Roman Catholics, such as celibacy, for example. But "in the end, it is the internal affair of both churches and it's not of essential importance for the action of unification" ${ }^{\text {,304 }}$.

Much space in the letter is devoted to the generally traditional dogmatic arguments about the primacy of the Pope and the role of the Eastern patriarchs. It is claimed that in the X century it was the Roman patriarch, equal among other patriarchs, who broke away from the cathedral Church, represented by the four universal patriarchs, and made a number of innovations, both ceremonial and dogmatic. Therefore, "in the understanding of all Orthodox, Ecumenical Church is a majority (four Ecumenical Patriarchs) who remained true to all the decrees of Ecumenical Councils, not a minority (one Roman Patriarch) who did not want to be equal with the latter in the spirit of Councils and departed from them both in dogmas and in church practice" ${ }^{305}$. Thus, even while maintaining the traditional Eastern rite, the psychology of the Orthodox will not be able to agree with many of the latest tenets of the Roman Church.

\footnotetext{
${ }^{303}$ Шептицький Андрей. Листи-послання (1939-1944). Львів, 1991. С. 346.

${ }^{304}$ Ibid. C. 347.

${ }^{305}$ Шептицький Андрей. Листи-послання (1939-1944). Львів, 1991. С. 347.
} 
While declaring their desire to work for the greatest possible understanding and agreement between the Greek Catholic and Orthodox Churches in the spirit of Christian love, the authors of the letter, however, believe that connecting the churches would be harmful to the Ukrainian people, and, therefore, propose to establish an inter-denominational cooperation only to help in the revival of the Orthodox Church, destroyed by the Bolsheviks. Among other things, in their opinion, "only our Orthodox hierarchs... can solve the problems of the relationship of our Orthodox Church with other churches, or only consider them"306.

Despite such a frankly destructive attitude to his proposals, Metropolitan Andrey Sheptytsky does not abandon his attempts to reach the mutual understanding. He again tries to explain to the intelligentsia what his action of unification (1941-1942) was all about. To this end, A. Sheptytsky prints his answers to the letters in the collection of documents "In the Case of Understanding".

In his opening remarks, Metropolitan notes that "the answers were so negative that only with good will one can think that at least some kind of understanding is possible. And many of the answers express an indignation that someone can suppose this. are quite outrageous that anyone can assume. Yet, these answers are such a large material for discussion that they cannot be silently omitted" ${ }^{307}$. Opening the discussion, Metropolitan Andrey made some preliminary remarks. First, A. Sheptytsky emphasizes that complete unity, that is, the formation of one religion, can only be achieved after a series of understandings. Therefore, the formation of a single church is more a matter of theory rather than practice. In reality, it is about reaching an understanding between different Ukrainian confessions in order to achieve national unity.

Secondly, A. Sheptytsky notes, his invitation to cooperate on the rapprochement of the Churches was understood by everyone only as a call for the complete union of the Orthodox with the Greek Catholics, and through it - the acceptance by all Orthodox the Union with the Apostolic See. Meanwhile, according to Metropolitan, it is possible to talk about different ways of understanding, without merging into one confession. "You could also think about the connection of the Orthodox denominations with Gr. Catholic, in which a new creed of both the united would arise, which would be neither ancient Orthodox nor ancient Gr. Cath. Church" "308. No one even thought of the possibility of such a multivariate interfaith relationship, because the idea of uniting the Churches was rudely reduced only to the Union.

\footnotetext{
${ }^{306}$ Ibid. C. 349.

${ }^{307}$ Ibid. C. 344.

${ }^{308}$ Шептицький Андрей. Листи-послання (1939-1944). Львів, 1991. С. 334.
} 
Answering the question about character of the connection, Metropolitan firmly rejects the allegation that it intends to subordinate completely the Ukrainian Churches to the Roman Catholic Church. He writes: "Single churches remain connected with all other churches in the West, they can retain far-reaching autonomy, which can be called autocephaly....,309. Moreover, according to A. Sheptytsky, Greek Catholics are ready, even with a loss for themselves, to surrender themselves to the power of the Metropolitan of Kyiv, if only he accepts the Universal faith.

It is interesting that representatives of the Orthodox intelligentsia - who in their attitude to A. Sheptytsky always tried to hold firmly to the historical ground - did not even notice in polemical passion how close the views of Metropolitan Andrey are to the project of the unity of the Churches, proposed three hundred years before by other great Metropolitan, and not a Greek Catholic one, but an Orthodox - Petro Mohyla... ${ }^{310}$

A. Sheptytsky refutes his opponents' assertion that the Roman Church is involved in the destruction of the Orthodox Churches and the persecution of believers in the Chelm Land and Volyn, finding them unproven. The appearance of such negative judgments is, in his opinion, because "you are often judging the activity of Roman Church, while being impressed by what the enemies of Christianity say or write about it.., but do not accept what is being told toYou about the Roman Church and its influence on us by the Ukrainians, who cannot be left behind by the position of Ukrainian patriotism"311.

A. Sheptytsky could not also ignore the field of history, to which the representatives of the Orthodox intelligentsia reduced the case of mutual understanding, although, as he himself points out, he is doing it without a pleasure. "I know," Metropolitan writes, "that when we seek mutual understanding and agreement between different Ukrainian confessions, it would be better to leave aside the arguments of history. During every reconciliation, even when it is not a question of joining and union, one must first say on both sides: "Forget it!" And the Lords would rather say, "We will not forget it to you!"312. According to A. Sheptytsky, such an approach, in which Greek Catholics of the XX century are declared responsible for the events of the XVI-XVII centuries and even the X-XI centuries, it is not constructive, it makes it impossible for religious and national understanding.

${ }^{309}$ Ibid. C. 349.

310 See.: Жуковський А. Петро Могила й питання єдности Церков. Париж, 1969. С. 121; 264; Історія церкви та релігійної думки в Україні: У 3-х книгах. Кн. 3. Кінець XVI - середина XIX століття. К., 1994. С. 62-69.

${ }^{311}$ Шептицький Андрей. Листи-послання (1939-1944). Львів, 1991. С. 351.

${ }^{312}$ Ibid. 
Metropolitan, however, does not avoid historical discussion, making two remarks. First, in his opinion, the Orthodox intelligentsia knows the history of the Union of Brest and its consequences from the writings of historians, who all, or almost all, were not only enemies of the Union of Churches, but also were enemies of the Ukrainian people. Therefore, their descriptions require careful review. Secondly, only such historical facts should be taken into account during the discussion, which no one can dispute.

In hir answers A. Sheptytsky thoroughly analyzes the main arguments of the opponents and presents hir own vision of historical processes. First of all, he refers to the events of 1596, that is, to the Union of Brest. "The fact is," he writes, "that the Union of Brest has been signed by all the bishops of the Kyiv ecclesiastical province, to which Bila Rus belonged. Two of the bishops, of Lviv and Przemysl, called out their Word"313. Therefore, if we follow the logic of the representatives of the Orthodox intelligentsia, who have declared that only Orthodox hierarchs are competent to solve the issues of inter-church relations, and the believers should follow them, then since the XVI century the history of the union of the Churches would go other ways. So, A. Sheptytsky states, there was a kind of double standard: what is good in the XX century is proclaimed a total evil for the XVIXVII centuries.

Another objection that the opponents made to Metropolitan is concerned with the historical events of the X century, that is, the split of the Churches. The arguments they put forward, according to Sheptytsky, "are not recorded historical facts" ${ }^{\prime 14}$, and he does not recognize them as such. In a letter from the Orthodox faithful intelligentsia, a quantitative approach was proposed to solve the question of what the true Universal Church is - Constantinople or Roman; Metropolitan Andrey proposes to look at the matter from another, qualitative side. Briefly, the essence of his argumentation is as follows: first, none of the Roman Bishops recognized the superstition of the patriarchs of Constantinople, while at least a dozen patriarchs of Constantinople recognized the superiority of the Roman throne. Secondly, there are no texts of St. Fathers who would argue that Constantinople exercised some kind of rule over Rome, while the reverse was recorded in several hundred texts. Thirdly, the Roman Bishops changed at least five Patriarchs of Constantinople, and there was not a single case to be vice versa. These and other facts cited by the Metropolitan in his answers, in his belief, undoubtedly attest to the right of the Apostolic See to be at the head of the Universal Church.

${ }_{314}^{313}$ Шептицький Андрей. Листи-послання (1939-1944). Львів, 1991. С. 354-355. 
Finally, another accusation of A. Sheptytsky's opponents is that the Roman Bishops "have made a number of innovations, both dogmatic and ceremonial, without asking the opinion of other patriarchs...,315. However, Sheptytsky says, Moscow Patriarch Nikon and Metropolitan Petro Mohyla of Kyiv, these great reformers of the rite and the church life, also made innovations, not seeking the consent of not only the Roman Bishop, but also of the Eastern Patriarchs. But for some reason their competence is beyond doubt for the Orthodox. As for dogmatic innovations, Metropolitan Andrey believes that none of them contradicts the teaching of the Church of the first 10 centuries. They are all aimed at "protecting the doctrine of the Divine Revelation against its new false understanding by establishing theological and philosophical terms that would describe and explain the old unchanging faith in a new word" ${ }^{316}$.

Unfortunately, this discussion did not continue. The malevolent attitude of Orthodox bishops and religious intellectuals to the ecumenical ideas of Metropolitan Andrey Sheptytsky, the prohibition of the German occupying power to publish any materials concerning the unification of the Ukrainian Churches, made it impossible for further unity.

Summing up A. Sheptytsky's long-standing activity in bringing together and uniting Churches, both Orthodox and Catholic, it should be emphasized once again that Metropolitan considered the matter of unity as priority over all his activities, he was ready to give his life for it. In our opinion, it is impossible to agree with the conclusion of one of the most famous researchers of his life and works, S. Baran: "In practice, Metropolitan's great religious plans came out with very little or nothing" ${ }^{317}$. If Great Metropolitan failed to fulfill the dream of his life, then his preparation did not go to waste, it became a valuable heritage, which can serve as a signpost for solving equally difficult problems of relations between two traditional Ukrainian denominations in modern Ukraine.

${ }^{315}$ Ibid. C. 358.

${ }^{316}$ Шептицький Андрей. Листи-послання (1939-1944). Львів, 1991. С. 405.

${ }^{317}$ Баран С. Митрополит Андрей Шептицький. Життя і творчість. Мюнхен, 1947. С. 353. 